\title{
Dynamics of Bacterial Communities Mediating the Treatment of an As-Rich Acid Mine Drainage in a Field Pilot
}

\author{
Elia Laroche 1,2, Corinne Casiot', Lidia Fernandez-Rojo', Angélique Desoeuvre ${ }^{1}$, \\ Vincent Tardy ${ }^{1}$, Odile Bruneel ${ }^{1}$, Fabienne Battaglia-Brunet ${ }^{2}$, Catherine Joulian ${ }^{2}$ and \\ Marina Héry ${ }^{1 *}$ \\ ${ }^{1}$ HydroSciences Montpellier, CNRS, IRD, University of Montpellier, Montpellier, France, ${ }^{2}$ BRGM, Geomicrobiology \\ and Environmental Monitoring Unit, Orléans, France
}

Passive treatment based on iron biological oxidation is a promising strategy for Arsenic (As)-rich acid mine drainage (AMD) remediation. In the present study, we characterized by $16 \mathrm{~S}$ rRNA metabarcoding the bacterial diversity in a field-pilot bioreactor treating extremely As-rich AMD in situ, over a 6 months monitoring period. Inside the bioreactor, the bacterial communities responsible for iron and arsenic removal formed a biofilm ("biogenic precipitate") whose composition varied in time and space. These communities evolved from a structure at first similar to the one of the feed water used as an inoculum to a structure quite similar to the natural biofilm developing in situ in the AMD. Over the monitoring period, iron-oxidizing bacteria always largely dominated the biogenic precipitate, with distinct populations (Gallionella, Ferrovum, Leptospirillum, Acidithiobacillus, Ferritrophicum), whose relative proportions extensively varied among time and space. A spatial structuring was observed inside the trays (arranged in series) composing the bioreactor. This spatial dynamic could be linked to the variation of the physico-chemistry of the AMD water between the raw water entering and the treated water exiting the pilot. According to redundancy analysis (RDA), the following parameters exerted a control on the bacterial communities potentially involved in the water treatment process: dissolved oxygen, temperature, $\mathrm{pH}$, dissolved sulfates, arsenic and Fe(II) concentrations and redox potential. Appreciable arsenite oxidation occurring in the bioreactor could be linked to the stable presence of two distinct monophylogenetic groups of Thiomonas related bacteria. The ubiquity and the physiological diversity of the bacteria identified, as well as the presence of bacteria of biotechnological relevance, suggested that this treatment system could be applied to the treatment of other AMD.

Keywords: acid mine drainage, arsenic, bioremediation, eco-engineering, iron-oxidizing bacteria, arsenicoxidizing bacteria, microbial ecotoxicology

\section{INTRODUCTION}

Mining activities produced large amount of wastes composed of sulfide minerals and toxic metallic elements, causing environmental hazard. During their inappropriate storage, oxidation of the sulfide minerals can generate acid mine drainage (AMD) characterized by acid $\mathrm{pH}$ and high concentrations in metals and metalloids. Arsenic (As) is a highly toxic metalloid often associated 
with this type of pollution (Paikaray, 2015). An AMD can selfsustain for several centuries, with dramatic consequences on the receiving aquatic ecosystems. In this context, the development of effective and sustainable remediation solution for the treatment of As-rich AMD is required for water resource and public health protection.

The dissemination of arsenic pollution can be naturally limited by its immobilization into the solid phase. This natural phenomenon relies on the biological oxidation of $\mathrm{Fe}(\mathrm{II})$ and its subsequent precipitation as Fe(III) oxyhydroxides. Arsenic is then removed from the dissolved phase by co-precipitation with $\mathrm{Fe}(\mathrm{III})$ or by adsorption to the newly formed ferric minerals. The less soluble form, arsenate $[\mathrm{As}(\mathrm{V})]$, is more efficiently trapped onto iron phases than the more mobile form, arsenite [As(III)] (Hug and Leupin, 2003). Then, the capacity of autochthonous bacteria to oxidize As(III) into As(V) together with the activity of iron-oxidizing bacteria $(\mathrm{FeOB})$ contribute to the mitigation of the arsenic pollution. This natural attenuation has been described at various mining sites worldwide (Casiot et al., 2003; Asta et al., 2010; Egal et al., 2010; Chen and Jiang, 2012; Paikaray, 2015), as well as the diversity of AMD autochthonous microbial communities (Baker and Banfield, 2003; Bruneel et al., 2011; Volant et al., 2014; Méndez-García et al., 2015; Chen et al., 2016). Several studies have focused on the identity of $\mathrm{FeOB}$ and $\mathrm{As}(\mathrm{III})$-oxidizing bacteria (AsOB) and their activity in relation with pollution attenuation (Battaglia-Brunet et al., 2002; Bruneel et al., 2003; Casiot et al., 2003; Duquesne et al., 2003; Egal et al., 2009). In particular, numerous evidences of the role of the As(III)-oxidizing Thiomonas spp. were reported (Bruneel et al., 2003, 2011; Casiot et al., 2003; Hovasse et al., 2016).

The development of passive treatment systems exploiting these microbially mediated processes is a promising strategy for the remediation of As-rich AMD (Hengen et al., 2014; Bruneel et al., 2017). The efficiency of such system was demonstrated in lab-scale bioreactors (González-Contreras et al., 2012; Hedrich and Johnson, 2014; Ahoranta et al., 2016; Fernandez-Rojo et al., 2017). Attempts of in situ treatment are scarce and mainly limited so far to AMD with arsenic concentrations lower than $3 \mathrm{mg} \mathrm{L}^{-1}$ (Whitehead et al., 2005; Macías et al., 2012). One field-pilot treating high arsenic concentrations (50-250 mg $\mathrm{L}^{-1}$ ) removed $20 \%$ of the dissolved arsenic (Elbaz-Poulichet et al., 2006). The treatment efficiency of these systems relies on microbial activity and thus may fluctuate depending on the identity and the dynamic of the microbial populations driving the biogeochemical reactions inside the bioreactor. Operating conditions as well as environmental conditions likely exert control over microbial diversity and activity (Heinzel et al., 2009b; Ahoranta et al., 2016; Fernandez-Rojo et al., 2017).

In a previous study, a passive field-scale bioreactor treating As-rich acid mine drainage from the Carnoulès mine (France) was monitored during 6 months (Fernandez-Rojo et al., in press). Arsenic removal varied between 3 and 97\% during the monitoring period for a flow rate variation between 6 and $130 \mathrm{~L}$ $\mathrm{h}^{-1}$. The proportion of $\mathrm{As}(\mathrm{V})$ in the biogenic precipitates formed inside the pilot increased over time, reaching nearly $100 \%$ of total As. Arsenate enrichment in the precipitate was associated with an increase of the abundance of the marker gene for bacterial arsenite oxidation (aioA) -quantified by qPCR-. Results strongly suggested that bacterial As(III) oxidation occurred in the bioreactor, leading to the formation of stable precipitates, advantageous in term of sludge management. However, the identity of the bacterial populations involved in arsenic and iron oxidation and removal were not determined. The aim of the present work was to improve our knowledge of the bacterial diversity driving As-rich AMD depollution in an in situ treatment device. In this context, the spatial and temporal dynamics of the bacterial communities colonizing the bioreactor were investigated by a $16 \mathrm{~S}$ rRNA metabarcoding approach. Because of their central role in arsenic oxidation in Carnoulès AMD, we further characterized two distinct monophyletic Thiomonas groups by CARD-FISH. We also focused on the physico-chemical drivers of the bacterial diversity. To our knowledge, this is the first microbiological characterization performed on a fieldpilot treating As-rich AMD by precipitation with biogenic iron phases.

\section{MATERIALS AND METHODS}

\section{Pilot Scale Passive Treatment System Description and Sample Collection}

A field-scale pilot, made with five shallow trays $(1.5 \times 1 \times 0.11 \mathrm{~m})$ stacked head to tail on a shelf, was implemented at the Carnoulès mine (France) for the treatment of AMD, as described in Fernandez-Rojo et al. (in press) (Figure 1A). The bioreactor was settled on June 2016 10th and was monitored during 194 days. Nine sampling campaigns were conducted and inlet water and biogenic precipitates were characterized for their physico-chemical properties (Fernandez-Rojo et al., in press). From the whole dataset and samples available, we selected seven dates for microbial characterization: 21st of June (D11); 29th of June (D19); 28th of July (D48); 3rd of October (D115); 28th of November (D171), 6th of December (D179), 13th of December (D186). Selection was based on the temporal variations of the $\mathrm{As}(\mathrm{V}) / \mathrm{Fe}$ molar ratio in the biogenic precipitate (Figure 1B). Arsenic removal rates from water and $\mathrm{Fe}(\mathrm{II})$ oxidation rates are also given. Biogenic precipitates were collected from tray 1 (T1) and tray 5 (T5) for all the campaigns and from tray 1,2, 3, 4, and 5 for the D48 and D171 campaigns.

Each tray was divided into three sections (Figure 1A): "a" refers to the location close to the inlet of the tray, "b" corresponds to the middle section, and " $\mathrm{C}$ " refers to the location close to the outlet of the tray. Based on ARISA (Automated Ribosomal Intergenic Spacer Analysis), bacterial community structures in the three sections $(a, b, c)$ of a given tray exhibited similar genetic structure (data not shown). Then, for each tray, samples collected in sections $\mathrm{a}, \mathrm{b}$ and $\mathrm{c}$ were used as triplicates for $16 \mathrm{~S}$ rRNA metabarcoding analyses. For each tray, three composite samples were collected in Falcon tubes $(50 \mathrm{~mL})$ by scrapping the biogenic precipitates in each section with a sterile spatula. The tubes containing the composite samples were 

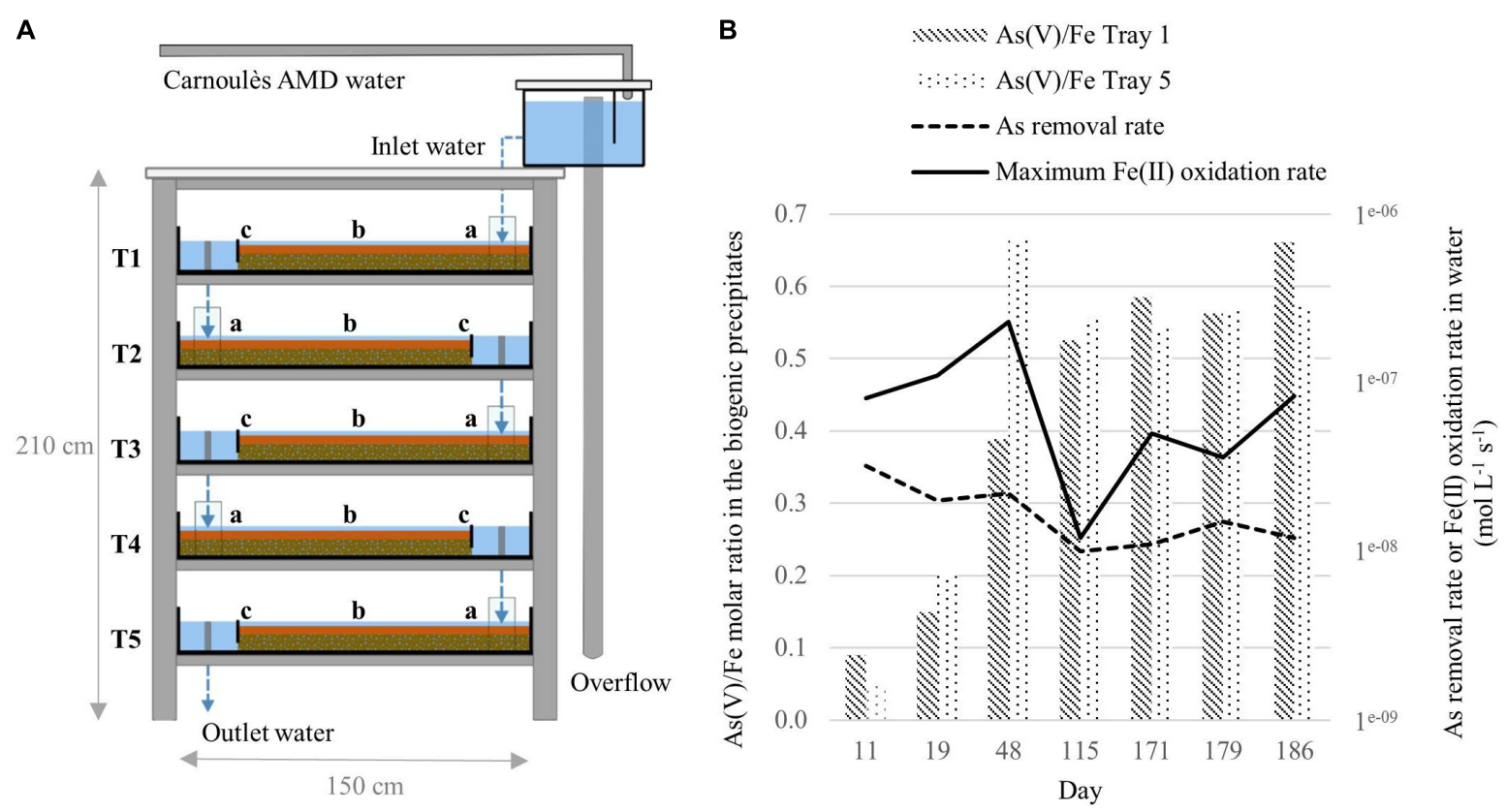

FIGURE 1 | Schematic representation of the field-bioreactor composed of five trays ( $T$ = tray) adapted from Fernandez-Rojo et al. (in press) (A). Arsenic removal rates calculated from inlet and outlet dissolved As concentration and estimated hydraulic retention time and maximum Fe(II) oxidation rates estimated from analytical uncertainty on dissolved Fe(II) determination, according to Fernandez-Rojo et al. (in press) (B).

centrifuged for $10 \mathrm{~min}$ at $4400 \times g$ (Sorwall ST40, Thermo Scientific). The supernatant was discarded and the precipitates were homogenized. An aliquot was dried in a vacuum desiccator for dry weight determination. The remaining precipitates were conserved in Eppendorf tubes $(2 \mathrm{~mL})$ at $-80^{\circ} \mathrm{C}$ before DNA extraction. Sample names refer to the sampling day (counted from the day of bioreactor settling, D1-D186) and the tray where the biogenic precipitate was sampled (T1-T5), e.g., D11-T1.

Inlet water was collected for all the campaigns but due to technical problem, water collected on October 3rd (D115) could not be analyzed. Triplicates of inlet water samples $(300 \mathrm{~mL})$ were filtered on sterile $0.22 \mu \mathrm{m}$ cellulose acetate filter. The filters were stored at $-80^{\circ} \mathrm{C}$ before DNA extraction. Water sample names refer to the sampling day (D1-D186) of inlet water sample $\left(\mathrm{W}_{\mathrm{in}}\right)$ (e.g., D11-W in).

For comparison between the bacterial communities established inside the bioreactor and the natural ecosystem, a point-in-time sampling of the AMD riverbed sediments (Reigous creek) was performed on the 28th of November (D171). Sediments (SED) were collected using a sterile spatula and were treated as described for the biogenic precipitates.

\section{Physico-Chemical Characterization of Inlet and Outlet Waters}

The chemical characterization of the water (inlet and outlet) and the bioprecipitate samples was performed in our previous study (Fernandez-Rojo et al., in press). Briefly, the concentrations of dissolved $\mathrm{Fe}$ (II) were determined using spectrophotometry after filtration through $0.22 \mu \mathrm{m}$. Total dissolved concentrations of $\mathrm{Fe}, \mathrm{As}$, and other elements [ $\mathrm{S}\left(\mathrm{SO}_{4}{ }^{2-}\right), \mathrm{Al}, \mathrm{Zn}$, and $\mathrm{Pb}$ ] were determined using ICP-MS. Arsenic redox speciation was determined using HPLC-ICP-MS. The data used in the present study are summarized in Figure $\mathbf{1 B}$ and Supplementary Table S1.

\section{DNA Extraction and Quantification}

Prior DNA extraction, biogenic precipitate and riverbed sediment samples were washed with $1 \mathrm{~mL}$ of TRIS-EDTA (100:40) $\mathrm{HCl} \mathrm{pH} 8$ and then centrifuged to $8,000 \times g$ from $1 \mathrm{~min}$. Total genomic DNA was then extracted using the DNeasy PowerSoil kit (Qiagen, Hilden, Germany), according to the manufacturer's recommendations (in triplicates for the biogenic precipitates). Extraction controls were performed without any biogenic precipitate sample to exclude any contamination from the kit. For water samples, DNA was extracted (in triplicates) from the cellulose acetate filters using DNeasy PowerWater kit (Qiagen) according to the manufacturer's recommendations. All the DNA extracts were quantified with a fluorometer (Qubit, Invitrogen, Carlsbad, CA, United States) and stored at $-20^{\circ} \mathrm{C}$ until further analysis.

\section{Sequencing of Bacterial 16S rRNA Gene}

The V4-V5 hypervariable region of the 16S rRNA gene was amplified using primers PCR 515F (Barret et al., 2015) and PCR 928R (Wang and Qian, 2009). PCR amplification was conducted as described in Tardy et al. (2018). Amplification performed on the control DNA extracts (obtained without any biogenic precipitate sample) yielded no amplification signal. The PCR products were sequenced with an Illumina MiSeq sequencer in 
paired-end mode $(2 \times 300 \mathrm{bp})$ at GeT-PlaGe platform (Toulouse, France).

\section{Bioinformatic Analyses of 16S rRNA Gene Sequences}

Pair-end sequences were merged by flash software version 1.2.6 (Magoè and Salzberg, 2011), with maximum 10\% of mismatch into the overlap region. The raw datasets are available on the EBI database system under project accession number [PRJEB27907]. The average Phred score (Q-score) of these joined reads was superior to 30 for every base. Bioinformatic analyses were conducted using the software program Mothur version 1.39.5 (Schloss et al., 2009). First step was the selection of high quality sequences based on the following criteria: length between 330 and $460 \mathrm{bp}$, a homopolymer length inferior to $7 \mathrm{nt}$ and no ambiguous bases. Singletons, chimeric and unaligned reads were removed using UCHIME (Edgar et al., 2011) and the SILVA reference database (Release 128). The pre-cluster command served to reduce sequencing noise by clustering reads differing by only one base every 100 bases. The high quality sequences were taxonomically assigned using the SILVA reference database, by the Bayesian method with a bootstrap confidence score of 80 (Wang et al., 2007). After the removal of sequences that were not assigned to the Bacteria kingdom, samples contained between 2227 and 34928 reads. A subsampling selected a random set of 6295 reads in each sample in order to efficiently compare the datasets. Samples containing less than 6295 reads were removed to maintain a sequencing effort that adequately covers the bacterial diversity. A distance matrix was generated with the remaining sequences and used to cluster these sequences into Operational Taxonomic Units (OTUs) defined at 97\% cutoff, using the average neighbor algorithm. Complementary analyses (based on BLAST) were performed for the assignation of the dominant OTU (representing $41 \%$ of the whole reads) at the genus level. Mothur used the OTU table to calculate the coverage sample (rarefaction curve), the alpha and beta diversity (diversity indices and Unifrac distances) at a level of $97 \%$ sequence similarity.

\section{CARD - FISH}

CARD-FISH analyses were performed in triplicates on biogenic precipitates collected from tray 1 (T1) and tray 5 (T5) on the $28^{\text {th }}$ of July (D48) and the 28th of November 2016 (D171). Oligonucleotide probes EUB338, EUB338II and EUB338III were used for Bacteria quantification (Amann et al., 1990; Daims et al., 1999). Negative controls were performed with probe NON338, the complementary sequence of EUB338 (Wallner et al., 1993). Two probes were used for the quantification of two distinct monophyletic groups of Thiomonas spp. Probes TM1G0138 and TM2G0138 respectively target Thiomonas group1 and group2 according to Hallberg et al. (2006), which correspond respectively to monophyletic Group II and I according to Coupland et al. (2004) and Bryan et al. (2009). Detailed protocol for in situ hybridization, tyramide amplification, and microscopic observations is provided in Supplementary File.

\section{Statistical Analyses}

All statistical analyses were performed with $\mathrm{R}$ version 3.4.3 using mainly vegan package $^{1}$. The statistically significant differences between CARD-FISH data were assessed with the non-parametric Kruskal-Wallis test followed by Dunn's post hoc test using Bonferroni $p$-value adjustment. Non-metric multidimensional scaling (NMDS), based on the weighted pairwise Unifrac distances, was used to illustrate the dynamics of the bacterial communities structure during the monitoring. The significance of the differences observed between groups of samples (phase I vs. phase II and tray 1 vs. tray 5) was assessed with an ADONIS test (999 permutations). Redundancy analysis (RDA) was performed to highlight the main environmental drivers shaping the bacterial community structure inside the bioreactor. This approach was chosen because an initial detrended correspondence analysis (DCA) indicated that bacterial community data had a linear distribution along the axis $(<3.0)$. The physico-chemical characteristics of the AMD water, measured in the inlet and outlet waters (Supplementary Table S1), were tested as environmental variables to explain the variations of dominant taxa in the bioprecipitates collected in tray 1 and tray 5 respectively (relative abundance of reads $\geq 1 \%$ in at least one bioprecipitate sample during the monitoring period). Indeed, the biofilm continually interacts with the inflowing water which provides the main energy source for the lithotrophic bacteria [Fe(II)]. Before the RDA, the normality of environmental variables was checked with a Shapiro-Wilk test. Environmental and biological variables were respectively log and Hellinger transformed (Legendre and Gallagher, 2001). A sub-set of environmental variables was selected to decrease the multicolinearity (variance inflation factors $<10$ ) and to include only the significant predictors $(p<0.05$ according Monte Carlo test with 999 permutations). Variation partitioning analyses enabled to evaluate the contribution of each variable to the bacterial community variation. The significance of the global model and the individual axes were checked with a Monte Carlo test (999 permutations).

\section{RESULTS}

\section{Bacterial Diversity and Structure in the Treatment Pilot}

Illumina sequencing of the 79 samples yielded a total of $2,288,823$ sequences of 16S rRNA gene. Among them, 6295 quality sequences per sample were sub-sampled for alpha and beta diversity analysis. Rarefaction curves approached an asymptote suggesting that the sequencing effort adequately covered the bacterial diversity in all the samples (Supplementary Figure S1).

In the biogenic precipitates, the richness increased from D11 to D19 as illustrated by the enrichment of observed OTUs (Figure 2A). At D11 and D19, richness was higher in the

\footnotetext{
${ }^{1}$ http://www.r-project.org/
} 

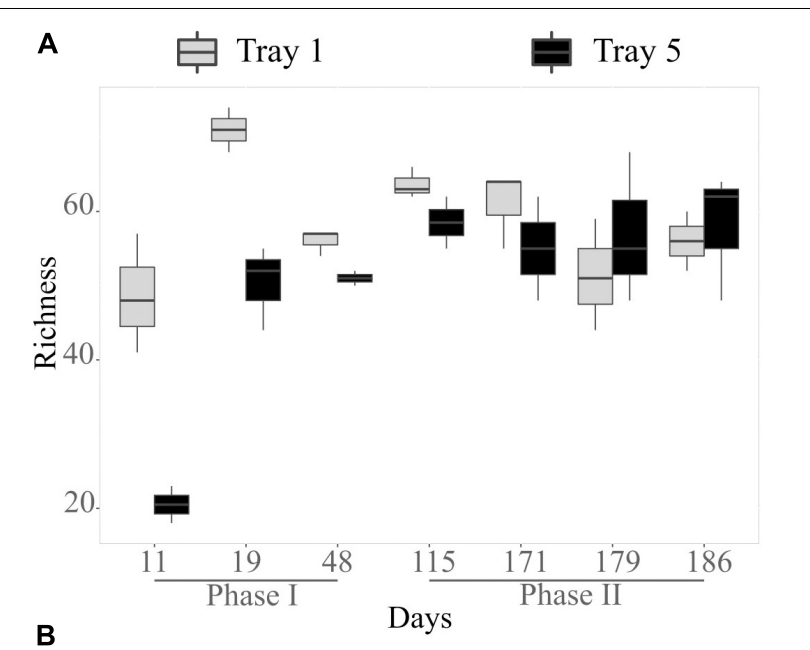

B
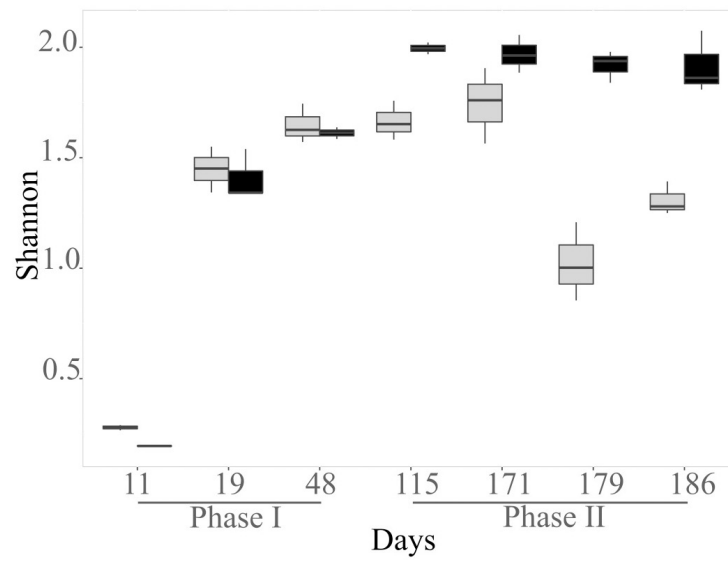

FIGURE 2 | Bacterial species richness in number of OTUs observed (A) and Shannon diversity index (B) in the biogenic precipitates collected in the tray 1 (light gray) and tray 5 (black). Error bars represent standard deviation of the mean value (analyses performed in triplicates).

top tray than in the bottom tray. From D48, the number of observed OTUs remained relatively stable and similar in both trays. Shannon index (reflecting both richness and evenness) also clearly increased during the first stages of the monitoring. Then it remained stable in tray 5 from D115 to D186, whereas it tended to decrease before increasing again in tray 1 (Figure 2B). Diversity indexes in the sediments collected in the AMD riverbed on day 171 (point in time analysis) were comparable to those measured in the biogenic precipitates collected at the same date in the top tray $(\mathrm{T} 1)$ (richness $=60$ observed OTUs; Shannon $=1.87$ ).

NMDS illustrates the dynamics of the structure of the bacterial communities in the biogenic precipitates and in the riverbed sediment (SED) (Figure 3). Samples were separated in two main groups (ADONIS test, $R^{2}=0.19, P=0.001$ ). The first group, composed by the communities at D11, D19, and D48, corresponded to the first phase of the monitoring (phase I). The second group, composed by the communities at D115-D186 corresponded to the second phase of the monitoring (phase II). In addition, over the whole monitoring period, the bacterial communities in the top tray (tray 1) were distinct from those thriving in the bottom tray (tray 5) (ADONIS test, $R^{2}=0.14$, $P=0.012$ ). This spatial structuring, visible from $\mathrm{D} 48$, became particularly marked from D115. Bacterial community thriving in the sediment collected in the AMD riverbed (SED) grouped with those of the biogenic precipitates collected at the same date (D171) in the top tray (Figure 3).

\section{Taxonomic Composition of the Bacterial Communities}

The majority of the 16S rRNA gene sequences retrieved from the biogenic precipitates, the riverbed sediments, and the AMD waters were affiliated with members of the Beta-Proteobacteria (between 65 and $99 \%$ of the total sequences). In the whole data set, the most abundant OTU was affiliated with genus Gallionella. Alpha- and Gamma-Proteobacteria were the second and the third most abundant taxonomic groups.

The composition of the bacterial communities remained relatively stable in the AMD waters over the monitoring period with always a large dominance of reads related to Gallionella (ranging from 63 to 96\%). Other minor groups identified in the waters included Sulfuriferula, Acidithiobacillus and Ferrovum (Supplementary Figure S2).

Eleven days after the pilot was set up (D11), the bacterial communities of the biogenic precipitates were quite similar to those of the feeding water and largely dominated by the Gallionella genus (Figure 4). Then, notable temporal shifts rapidly occurred in the composition of the bacterial communities of the biogenic precipitates (phase I). From the 29th of June (D19), the proportion of Gallionella strongly decreased while those of Sulfuriferula, Ferrovum, Rickettsiales, Ferritrophicum and Acidithiobacillus increased. Sulfuriferula was dominant in the pilot between D48 and D171. From D115, the bacterial communities in the top tray and in the bottom tray were clearly distinct (phase II). The composition of the communities in T5 remained relatively stable, whereas in $\mathrm{T} 1$, the relative proportion of Gallionella increased again during this second phase of the monitoring (Figure 4).

Overall, for the whole monitoring period, the top tray was characterized by higher proportion of Gallionella compared to the bottom tray. Sulfuriferula, Ferrovum, Ferritrophicum, Acidithiobacillus, Leptospirillum and Acidicapsa were more abundant in the bottom tray. Spatial structuring inside the pilot was confirmed with the characterization of the bacterial communities in the five trays for two sampling campaigns (D48 and D171). This analysis showed that communities thriving in tray 2 were comparable to those in tray 1 whereas communities thriving in trays 3 and 4 were comparable to those in tray 5 (Supplementary Figure S3).

The composition of the bacterial community in the sediments (SED) collected in the AMD riverbed at D171, was similar to that of the biogenic precipitates collected the same day inside the top tray (T1) of the bioreactor (Figure 4). The relative proportion of Thiomonas in the Reigous creek sediments was comparable to that in the top tray of the treatment device $(1.1 \%$ and $0.89 \pm 0.25 \%$ respectively). The proportion of Acidithiobacillus 


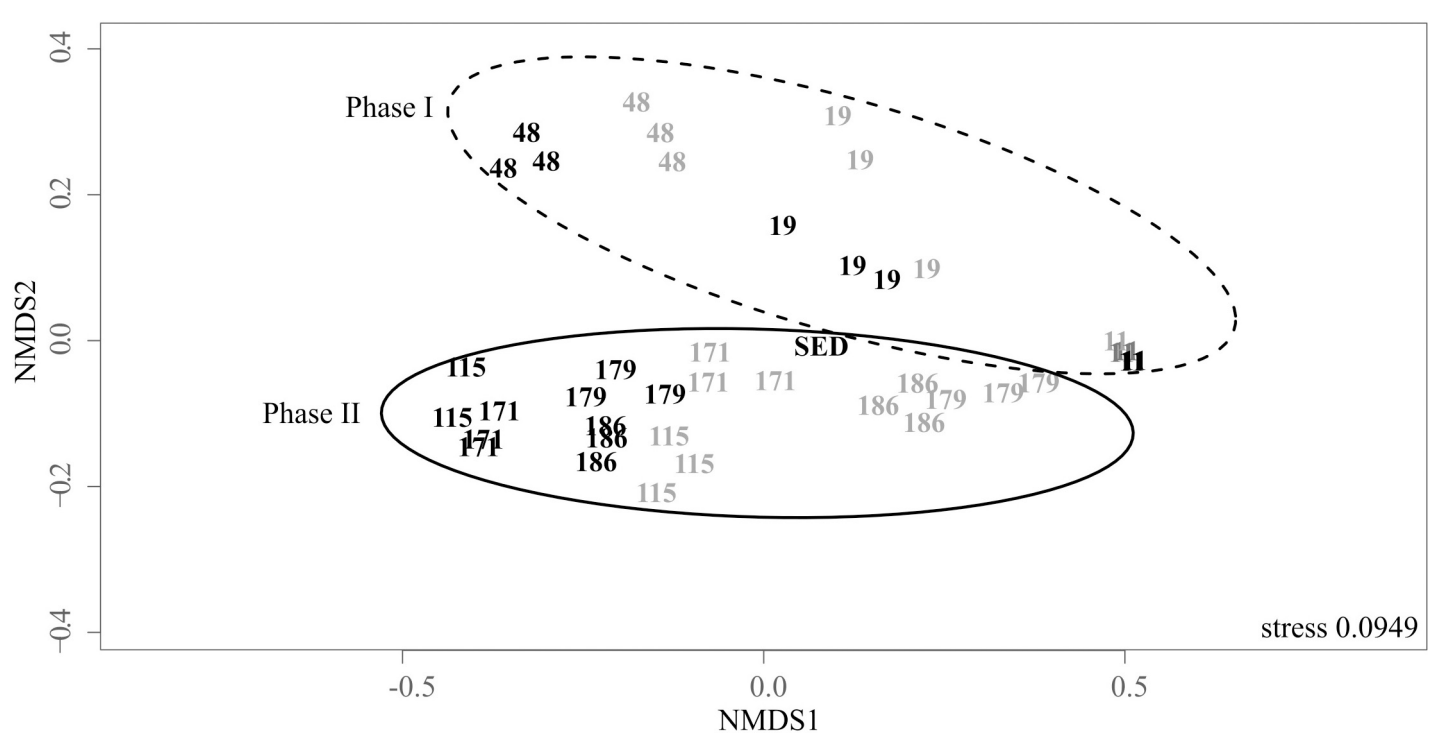

FIGURE 3 | Non-metric multidimensional scaling (NMDS) ordination plot of the weighted pairwise Unifrac distances of the bacterial community in the biogenic precipitates collected on the seven campaigns (the numbers indicate the days of sampling) in the tray 1 (gray) and the tray 5 (black) of the bioreactor (analyses performed in triplicates) and in the riverbed sediment (SED) collected on day 171. Stress values for ordination plot were $<0.2$ which indicates that these data were well-represented by the two-dimensional representation.

was higher in the treatment pilot $(2.8$ and $9 \%$ respectively in tray 1 and 5$)$ than in the riverbed sediment $(0.6 \%)$.

\section{Quantification of Thiomonas Populations by CARD-FISH}

Total bacteria and two distinct monophyletic groups of Thiomonas-related bacteria were quantified in the biogenic precipitates sampled in $\mathrm{T} 1$ and $\mathrm{T} 5$ at D48 (28th of July) and D171 (28th of November) by CARD-FISH (Table 1 and Supplementary Figure S4). Biogenic precipitates contained an average of $8 \pm 310^{7}$ total bacterial cells/g of dry biogenic precipitates. No significant differences $(p>0.05)$ were observed for the total number of bacteria among the four samples analyzed. The total number of Thiomonas averaged $7 \pm 210^{6}$ cells/g of dry biogenic precipitates, representing $8 \%$ of the DAPI-stained cells. Thiomonas belonging to group II (as defined by Bryan et al., 2009) were more abundant in the pilot than Thiomonas belonging to group I $(p<0.05)$. They corresponded respectively to an average of 4.9 and $3.1 \%$ of the DAPI-stained bacteria (Table 1). If no temporal differences were observed between D48 and D171, the total number of Thiomonas (Group I + II) was significantly higher in the bottom tray (T5) compared to the top tray (T1) in November (D171) $(p<0.05)$.

\section{Main Drivers Shaping the Bacterial Communities Inside the Pilot}

Redundancy analysis (RDA) summarized the spatio-temporal dynamics of the bioprecipitates bacterial communities and highlighted the main environmental factors explaining these variations. The samples were arranged according to the same pattern as in the NDMS (Figure 5). The model explained significantly $83.3 \%$ of bacterial community variation (Monte Carlo test, $P<0.05)$. According to variation partitioning, the dissolved oxygen (DO) was individually the best driver of this

TABLE 1 | Quantification by CARD-FISH of Thiomonas belonging to Group I (bacteria hybridized with the oligonucleotide probe TM2G0138) and of Thiomonas belonging to Group II (bacteria hybridized with the oligonucleotide probe TM1G0138).

\begin{tabular}{|c|c|c|c|c|c|c|}
\hline \multirow[b]{2}{*}{ Sample name } & \multicolumn{2}{|c|}{ Thiomonas Group I } & \multicolumn{2}{|c|}{ Thiomonas Group II } & \multicolumn{2}{|c|}{ Bacteria (EUB I-III) } \\
\hline & $\begin{array}{c}\text { No of cells/g of } \\
\text { dry biogenic } \\
\text { precipitate }\end{array}$ & $\begin{array}{c}\% \text { of } \\
\text { DAPI-strained } \\
\text { cells }\end{array}$ & $\begin{array}{c}\text { No of cells/g of } \\
\text { dry biogenic } \\
\text { precipitate }\end{array}$ & $\begin{array}{c}\% \text { of } \\
\text { DAPI-strained } \\
\text { cells }\end{array}$ & $\begin{array}{c}\text { No of cells/g of } \\
\text { dry biogenic } \\
\text { precipitate }\end{array}$ & $\begin{array}{c}\% \text { of } \\
\text { DAPI-strained } \\
\text { cells }\end{array}$ \\
\hline D48-T1 & $2 \pm 1 \times 10^{6}$ & $3 \pm 2$ & $5 \pm 3 \times 10^{6}$ & $6 \pm 2$ & $6.1 \pm 0.7 \times 10^{7}$ & $88 \pm 1$ \\
\hline D48-T5 & $3 \pm 2 \times 10^{6}$ & $4 \pm 3$ & $5 \pm 3 \times 10^{6}$ & $5 \pm 3$ & $7 \pm 5 \times 10^{7}$ & $82 \pm 1$ \\
\hline D171-T1 & $1.0 \pm 0.3 \times 10^{6}$ & $2.0 \pm 0.7$ & $3.4 \pm 0.2 \times 10^{6}$ & $4.6 \pm 0.9$ & $6 \pm 1 \times 10^{7}$ & $87 \pm 2$ \\
\hline D171-T5 & $4 \pm 3 \times 10^{6}$ & $4 \pm 2$ & $6 \pm 2 \times 10^{6}$ & $5 \pm 2$ & $1.2 \pm 0.8 \times 10^{8}$ & $83 \pm 3$ \\
\hline
\end{tabular}

Standard deviations were calculated on biological triplicates. 

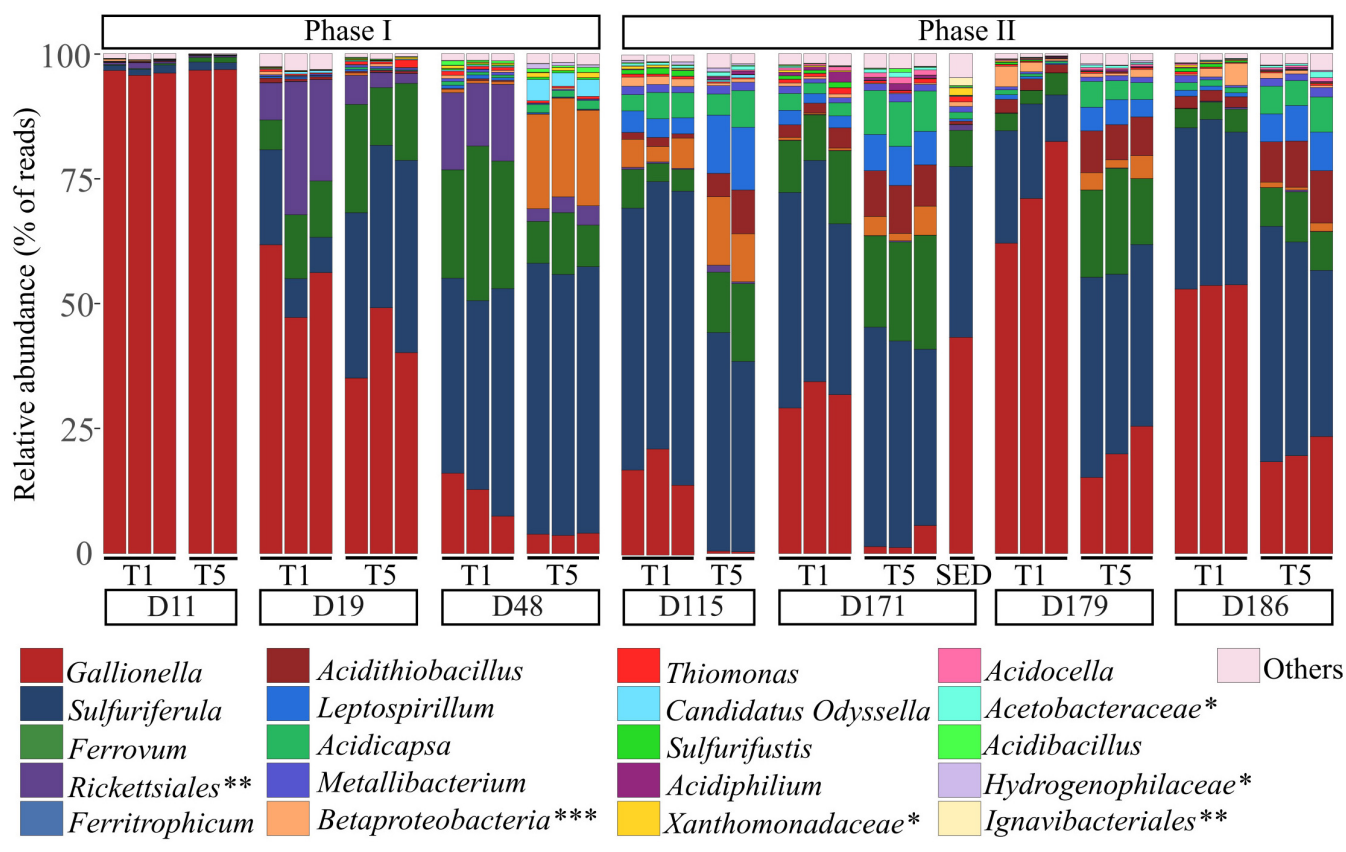

FIGURE 4 | Taxonomic composition of bacterial communities (at the genus level) in the biogenic precipitates collected on the seven campaigns in the tray 1 (T1) and the tray 5 (T5) of the bioreactor (analyses performed in triplicates) and in the riverbed sediment (SED) collected on day 171. When genus identification was not possible, classification was made at the family level $\left(^{*}\right)$, the order level $\left(^{* *}\right)$ or the class level (***). "Others" represent the phylogenetic groups with a relative abundance $<1 \%$ calculated on the whole dataset.

variability accounting for $36.5 \%$ of the total variance. It was followed by sulfate concentration $(26.7 \%)$, temperature $(16.5 \%)$, $\mathrm{pH}(15.2 \%)$, dissolved arsenic and ferrous iron concentration (11.1\% and 10.2\%, respectively) and the redox potential Eh (6\%).

The bacterial communities thriving in the pilot during the first phase were clearly distributed along a temporal gradient and were associated with high values of temperature, $\mathrm{pH}$, dissolved arsenic, and ferrous iron concentrations, and by low values of DO and Eh. Between D115 and D186, samples were divided into two subgroups corresponding respectively to tray 1 and tray 5. During this second phase, the structure of the bacterial communities was explained by high DO and Eh values, particularly in the tray 5 (Figure 5).

The cosine of the angle between an environmental variable and a bacterial taxa provides an approximation of their correlation. Thus, it can be inferred from Figure 5 that the relative abundance of Rickettsiales was positively correlated with water temperature and negatively with Eh. On the contrary, Acidithiobacillus, Leptospirillum and Acidicapsa were negatively correlated with temperature, $\mathrm{pH}$ and arsenic concentration in water and positively with Eh and DO. For the other taxa, no clear correlations could be drawn.

\section{DISCUSSION}

In the in situ treatment device, iron and arsenic removal was driven by a microbial biofilm colonizing the surface of the five trays composing the pilot. The present study aimed at characterizing the bacterial diversity and its spatio-temporal dynamics in this engineered system, in relation with main environmental parameters.

\section{Microbiology of the Bioprecipitates}

The biogenic precipitates that developed inside the pilot contained at least one order of magnitude higher bacterial biomass than what was observed in a lab-scale pilot treating the same AMD (Fernandez-Rojo et al., 2017) and in terraced iron formations reported elsewhere (Brown et al., 2011; Brantner et al., 2014). Thus, both the sand used to fill the trays and the hydrodynamic conditions were favorable to a biofilm development. The microbial assemblages developing inside this engineered system reproduced, at least partially, the natural ecosystem established in the nearby AMD. The microbiology of the pilot was largely dominated by diverse iron-oxidizing bacteria (FeOB): Gallionella, Ferrovum, Ferritrophicum and, to a lesser extent, Acidithiobacillus and Leptospirillum. The main taxa identified were previously found in AMD ecosystems (Baker and Banfield, 2003; Baker et al., 2003; Méndez-García et al., 2015; Chen et al., 2016), including Carnoulès (Bertin et al., 2011; Bruneel et al., 2011; Volant et al., 2014), and in laboratory-based experiments (Fernandez-Rojo et al., 2018; Tardy et al., 2018).

Gallionella proved to be dominant in the Carnoulès ecosystem (Bruneel et al., 2006; Volant et al., 2014; Tardy et al., 2018) and in a lab-scale pilot treating Carnoulès water (Fernandez-Rojo et al., 2018). Genus Ferrovum, containing litho-autotrophic acidophilic FeOB with potential biotechnological relevance (Heinzel et al., 2009a,b; Hedrich and Johnson, 2012), was also described in 


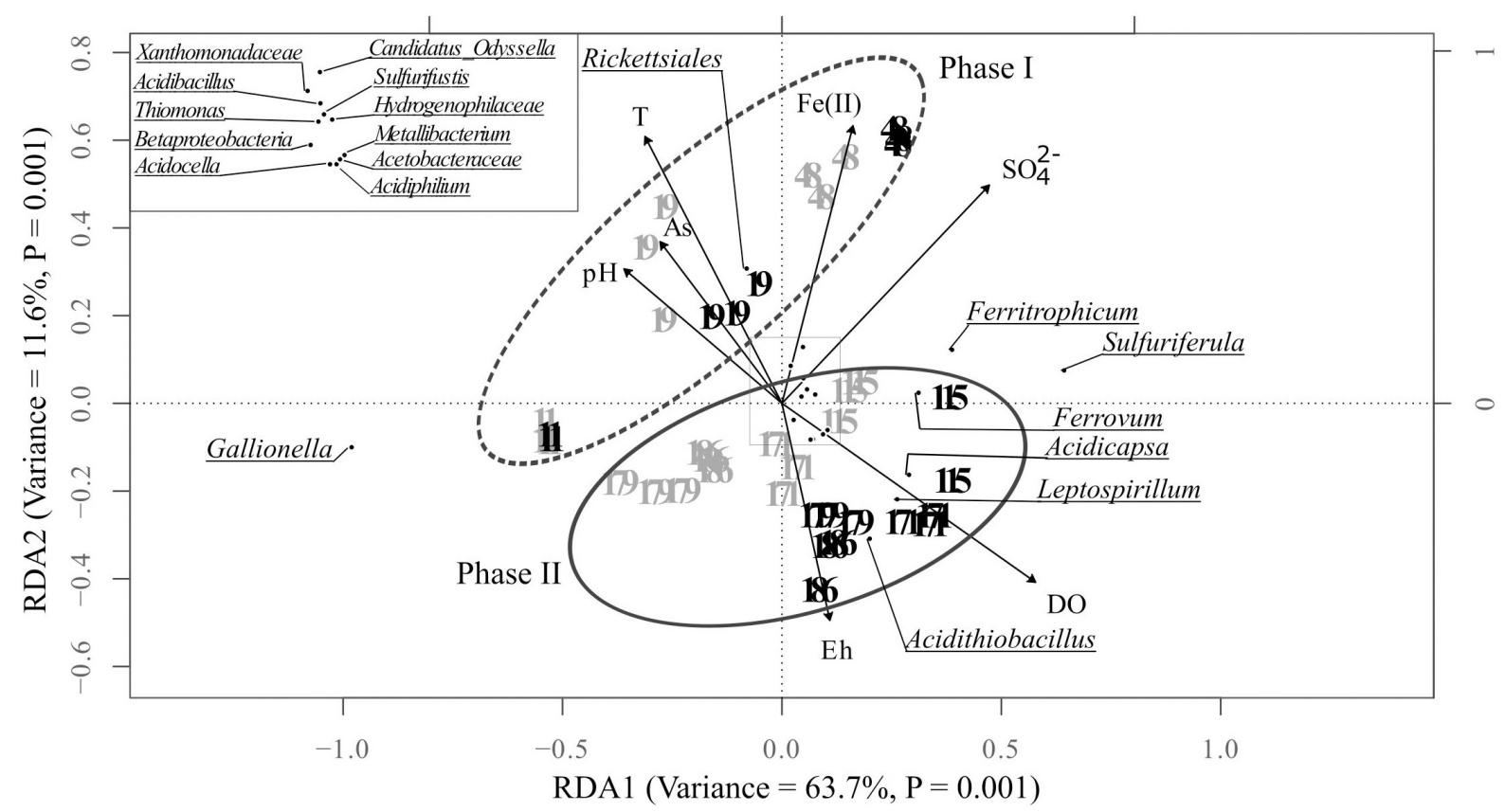

FIGURE 5 | Redundancy analysis (RDA) illustrating the relationships between the environmental variables (DO, dissolved oxygen; $\mathrm{SO}_{4}{ }^{2-}$, dissolved sulfate concentration; T, temperature; $\mathrm{pH}$, As, dissolved arsenic concentration; Fe(II), dissolved ferrous iron concentration and the redox potential Eh) and the distribution of the major bacterial taxa in the bioprecipitates collected on the seven campaigns in the tray 1 (gray) and the tray 5 (black) of the bioreactor (only the taxa with a relative abundance $\geq 1 \%$ in at least one bioprecipitate sample are included in this analysis). The analyses were performed in triplicates. The inset represents a close-up view of the center part of the RDA plot.

diverse AMD, including iron-rich environments (Johnson et al., 2014). Gallionella and Ferrovum were dominant in pilot plants relying on biological iron oxidation (Heinzel et al., 2009a,b; Hedrich et al., 2011; Hedrich and Johnson, 2012; Tischler et al., 2014; Sheng et al., 2016; Sun et al., 2016). Ferritrophicum genus, also including FeOB (Weiss et al., 2007), was previously identified in AMD (González-Toril et al., 2011; Tardy et al., 2018).

The moderately acidic sulfur oxidizers Sulfuriferula spp. were described as potential key actors of sulfur-cycling in acidic mine waste containing sulfide minerals (Jones et al., 2017). Their abundance in the pilot may be linked to the inflow of sulfide particles from the tailing pile into the pipe carrying the AMD water. The recent taxonomic reclassification of Thiobacillus plumbophilus to Sulfuriferula plumbophilus (Watanabe et al., 2015) may explain why Sulfuriferula spp. were underestimated so far in AMD. The capacity to oxidize iron or arsenic has not been described for any known Sulfuriferula species. "Sulfurdriven As(III) oxidation" was suggested in alkaline mono lake, through microbial thioarsenate transformation (Fisher et al., 2008). However, it is unlikely that similar process occurs under acidic and fully oxic conditions. Understanding the role of this genus (which mostly dominated the system from D48) in the treatment process requires further investigations.

Acidithiobacillus is considered as an important player in the attenuation process in Carnoulès (Egal et al., 2009; Bruneel et al., 2011; Bertin et al., 2011). This FeOB was detected in variable but relatively low proportions in the bioprecipitate (from 0.03 to $10.5 \%$ ), in agreement with previous in situ observations
(Volant et al., 2014). Sensibility to Fe(II) could explain the low abundance of Acidithiobacillus and the dominance of Ferrovum and Gallionella in the field-pilot where Fe(II) concentrations ranged between 649 and $1396 \mathrm{mg} \mathrm{L}^{-1}$ (Jones et al., 2015). The importance of Acidithiobacillus in biooxidation plants has previously been questioned (Rawlings et al., 1999). Even when used as an inoculum, A. ferrooxidans was out competed by Ferrovum in a pilot plant treating acid mine waters (Heinzel et al., 2009a). Distinguish the specific contribution of each FeOB population to iron and arsenic removal in the present study would require further investigations.

The presence of iron-reducing bacteria (Acidiphilium, Acidocella, Metallibacterium) can be explained by the occurrence of anoxic niches inside acidophilic biofilm (Ziegler et al., 2013).

\section{Dynamics of the Bacterial Communities Inside the Pilot}

During the monitoring, biofilm colonization (phase I) was followed by a stationary phase (phase II) reached by the mature biofilm, and characterized by a stable bacterial biomass. The dominance of Gallionella in the bioprecipitates at the very beginning of the monitoring was linked to their dominance in the water used to feed the pilot. As the biofilm matured, spatial heterogeneities arose, resulting in the diversification of micro-habitats advantageous for other populations (Santegoeds et al., 1998; Woodcock and Sloan, 2017). The proportion of Sulfuriferula, Ferrovum, Ferritrophicum, Rickettsiales increased 
while those of the first colonizers Gallionella decreased. Increase of bacterial diversity and shifts in bacterial assemblages were previously described during acidophilic biofilm maturation (Wilmes et al., 2009; Mueller et al., 2011).

Ferrovum myxofaciens produces large amounts of extracellular polymeric substances, which facilitate attachment to surfaces (Rowe and Johnson, 2008). This capacity may provide a competitive advantage to Ferrovum-related bacteria in engineered systems. In two pilot plants treating acid mine water, Gallionella were dominant during a first phase associated with unstable operating conditions while Ferrovum became dominant during a second phase with stable conditions. Gallionella abundance increased again at the end of the monitoring (Heinzel et al., 2009b). Similarly, in the present study, Gallionella regained in importance during the later stages of the monitoring, particularly in the top tray.

The autochthonous bacterial communities of the AMD feeding the pilot remained stable and largely dominated by Gallionella during the 6 months monitoring. Thus, the temporal dynamic of the bacterial community in the bioprecipitate (particularly during phase I) can be more readily attributed to bacterial succession during biofilm establishment rather than to the modification of the seeding community.

During the second phase of the monitoring, the spatial structuring of the mature communities inside the pilot intensified. Differences observed between the top and the bottom trays can be linked to a modification of the chemistry of the overlying water while transiting inside the pilot. This chemical gradient between the inlet and the outlet water was particularly marked during this second phase (Supplementary Table S1).

\section{Influence of Environmental Parameters on the Bacterial Communities}

The range of physico-chemical variations observed in the AMD water during the 6 months monitoring was representative of the seasonal variations described during a 4 years in situ monitoring (Egal et al., 2010). The present study covered both summer (phase I) and autumn (phase II) periods. Thus, a seasonal effect on the whole dynamic may not be excluded. However, both autogenic (e.g., internal and biotic) and allogenic (e.g., external and abiotic) parameters are likely to govern bacterial dynamics during biofilm establishment. It is then difficult to distinguish the effect of seasonal variations from the autogenic parameters that may be particularly influential during the early phases of the biofilm development (Jackson et al., 2001; Lyautey et al., 2005). However, we can assume that once the biofilm has reached its maturity, the bacterial community dynamic was mainly driven by the variations of the physico-chemistry of the overlying water (Brown et al., 2011).

Redundancy analysis highlighted the key parameters susceptible to influence bacterial diversity in the pilot: DO, sulfate concentration, temperature, $\mathrm{pH}$, dissolved As and $\mathrm{Fe}(\mathrm{II})$ concentration, and Eh (Rawlings et al., 1999; Dopson et al., 2007; Kupka et al., 2007; Candy et al., 2009; Volant et al., 2014; Jones et al., 2015; Sheng et al., 2016).
Gallionella is a microaerophilic bacteria thriving at lower oxygen conditions than other FeOB as Ferrovum, A. ferrooxidans and Leptospirillum spp. (Hanert, 2006; Johnson et al., 2014). The persistence of microaerophilic bacteria in the bioprecipitates and in the sediments, including some Gallionella and Ferritrophicum (Weiss et al., 2007), could be explained by the possible occurrence of microaerobic niches, as seen elsewhere (Ziegler et al., 2013). On the contrary, higher abundances of Ferrovum were associated with increasing concentration of oxygen (Jwair et al., 2016; Fabisch et al., 2016; Fernandez-Rojo et al., 2018).

Most of the FeOB characterized so far are mesophilic or thermophilic (Kupka et al., 2007). A better tolerance to low temperatures of Acidithiobacillus (Norris, 1990) may explain why its abundance was negatively correlated with temperature in the pilot. Batch experiments conducted with Carnoulès AMD water showed a clear effect of temperature on arseniteoxidizers: both the abundance of Thiomonas and the As(III) oxidation activity were stimulated at $35^{\circ} \mathrm{C}$ compared to $20^{\circ} \mathrm{C}$ (Tardy et al., 2018). In the temperature range covered by the present study $\left(5.2-23.8^{\circ} \mathrm{C}\right)$, no correlation was evidenced between temperature and Gallionella, Ferrovum or Thiomonas relative abundances. Temperatures naturally reaching $30^{\circ} \mathrm{C}$ or more in the water column above the bioprecipitate during summer are not excluded, particularly in case of reduced water height and long residence times. Such high temperatures may have differential effect on the $\mathrm{FeOB}$ and $\mathrm{AsOB}$ activity depending on their physiology.

Regarding the $\mathrm{pH}$, our results are congruent with the better adaptability of Ferrovum, Acidithiobacillus, and Leptospirillum to acidic conditions compared to Gallionella known to prefer $\mathrm{pH}$ above 3 (Rawlings et al., 1999; Jones et al., 2015; Grettenberger et al., 2017).

$\mathrm{Fe}(\mathrm{II})$ concentration also influences growth and activity of FeOB depending on their affinity for this energy source and on potential competition between different populations (Battaglia et al., 1994; Rawlings et al., 1999). The negative correlation of Acidithiobacillus with $\mathrm{Fe}(\mathrm{II})$ is in agreement with a previous study (Jones et al., 2015). Furthermore, different affinity for $\mathrm{Fe}(\mathrm{II})$ together with distinct sensitivity to $\mathrm{Fe}(\mathrm{III})$ inhibition may explain the effect of redox potential (conditioned by the ratio $\mathrm{Fe}(\mathrm{III}) / \mathrm{Fe}(\mathrm{II})$ ) on the relative distribution of $\mathrm{FeOB}$ (Rawlings et al., 1999; Meruane et al., 2002; Kuang et al., 2013).

Occurrence of Gallionella was negatively correlated with sulfate concentrations. Sulfates are generally well tolerated by FeOB, with inhibitory effects reported for concentrations higher than the ones measured in the present study (Candy et al., 2009). However, sulfate concentrations were previously shown to drive bacterial community composition in the Carnoulès AMD waters (Volant et al., 2014).

Finally, dissolved arsenic concentration significantly contributed to the bacterial community structure inside the bioreactor. Similar influence was shown in situ (Volant et al., 2014). Nevertheless, no tendency was highlighted between the variations of dissolved arsenic concentration and the proportion of the arsenite-oxidizing Thiomonas. It can be hypothesized that in the range of concentrations measured in this study, arsenic was not a limiting factor for bacteria relying on arsenite oxidation 
for their growth, and was not toxic for the others Thiomonas. Acidithiobacillus appeared to be negatively correlated with dissolved arsenic concentration although high resistance capacity was evidenced for some strains of $A$. ferrooxidans (up to $15 \mathrm{~g} \mathrm{~L}^{-1}$ As(III), Dave et al., 2008). A possible explanation is that Acidithiobacillus contribute to arsenic removal from water and its abundance in the bioprecipitates is thus associated with lower dissolved arsenic concentrations.

\section{Iron Oxidation and Precipitation}

In spite of the large dominance of $\mathrm{FeOB}$ in the pilot, iron oxidation and precipitation did not exceed $20 \%$ and $11 \%$, respectively (Fernandez-Rojo et al., in press). Iron-oxidizing activity of $A$. ferrooxidans was strongly inhibited when the bacteria were attached to solid surfaces (Wakao et al., 1984). On the contrary, Ferrovum biofilms proved to be very effective in iron-oxidizing bioreactors (Hedrich and Johnson, 2012). Among several strains tested by Johnson et al. (2012) the highest iron oxidation rates were obtained with Ferrovum spp. In spite of their well-known efficiency and their adaptation to temperature and $\mathrm{pH}$ ranges observed in the pilot (Kuang et al., 2013; Johnson et al., 2014; Jones et al., 2015), the iron-oxidizing activity of FeOB (including Ferrovum) appeared limited in the present study possibly because of non-optimal operating conditions. The water height above the biofilm $(1.5-7 \mathrm{~cm})$, which is a key factor for iron oxidation kinetics, may have prevented a sufficient oxygenation of the water column (Brown et al., 2011; Fernandez-Rojo et al., 2017). Another possible limiting factor is an insufficient active surface of the biofilm in regard to the volume of overlying water to be treated. Probably due to these limitations, the important variations of FeOB distribution inside the pilot did not result in significant iron oxidation rate variation (Figure 1B). Our results strongly suggest that the composition of the bacterial communities was not a limiting factor for iron oxidation in the bioreactor. Further work based on RNA will help to determine which bacterial taxa actively contribute to the treatment.

\section{Bacterial Arsenite Oxidation in the Pilot}

As(III) oxidation by Thiomonas spp. can contribute to the formation of stable As(V)-rich precipitates. No clear temporal or spatial tendency was observed for Thiomonas genus based on metabarcoding. Further insights into the abundance and the identity of the Thiomonas spp. thriving in the pilot were gained by a CARD-FISH approach. In the biogenic precipitates sampled at D48 and D171, the proportion of Thiomonas related bacteria averaged $8 \%$ of the DAPI-stained bacteria, which is congruent with in situ observations (5-8.7\%, Hovasse et al., 2016). Despite their low abundance, Thiomonas-related bacteria are considered to play a crucial role in the pollution mitigation (Bruneel et al., 2003, 2011; Hovasse et al., 2016). Metaproteomic approaches showed that they sustainably express an arsenite oxidase activity in situ in Carnoulès (Bertin et al., 2011; Hovasse et al., 2016). Inside the pilot, the Thiomonas belonging to group II (as defined by Bryan et al., 2009) were more abundant than those belonging to group I $(p<0.05)$, whereas the average proportions of the two groups were similar in situ (Hovasse et al., 2016). Both groups I and II contain arsenite-oxidizing Thiomonas strains isolated from the Carnoulès AMD (Bryan et al., 2009; Bertin et al., 2011; Hovasse et al., 2016). Group II includes Thiomonas sp. CARN2, which expressed its arsenite oxidation activity in the Carnoulès AMD sediments (Bertin et al., 2011). The As(III)-oxidation genetic potential (expressed as the number of aio $A$ genes $\mathrm{ng}^{-1}$ of DNA) increased tenfold in the bioprecipitate during the first 48 days suggesting the establishment of an active As(III)oxidizing bacterial population during the early stages of the biofilm maturation (Fernandez-Rojo et al., in press). Although the detection of aio $A$ genes doesn't give evidence of its expression, we can hypothesize that the Thiomonas-related bacteria identified by CARD-FISH were responsible for the arsenic oxidation resulting in the formation of solid phases containing almost 100\% of $\mathrm{As}(\mathrm{V})$.

\section{CONCLUSION}

The present study gave new insights into the bioremediation, at the field-scale, of As-rich AMD by biological iron and arsenic oxidation. Bacterial communities originating from the AMD water and organized in biofilm inside the pilot successfully removed soluble arsenic. It can be assumed that, during the first phase of the monitoring, the temporal dynamic of the biogenic precipitates communities was mostly due to ecological succession during biofilm installation. Once the biofilm was mature, the physico-chemistry of the overlying water exerted a complex control on the distribution of the biofilm bacterial populations. The co-existence of several FeOB populations characterized by distinct physiological traits (in term of optimal $\mathrm{pH}$, temperature, DO, and $\mathrm{Fe}(\mathrm{II})$ affinity...) permitted a good adaptation of the system toward variations in the chemistry of the AMD water to be treated. Ubiquity of the bacteria identified and the presence of bacteria of biotechnological relevance (Ferrovum, Acidithiobacillus) let expect that the application of this system to other As-and Fe-rich AMD worldwide is practicable.

We showed evidence of the stable presence of distinct populations of Thiomonas spp. in the pilot. Appreciable arsenite oxidation occurred in the field pilot. To determine the factors controlling arsenite oxidation activity in this treatment system, gene expression investigations are required.

The development of accurate biological treatment requires the stability of bacterial activity under seasonal variations. Furthermore, the bacterial diversity of the AMD water remained relatively stable during the 6 months monitoring whereas it proved to be more variable over a longer period of time (Volant et al., 2014). For these reasons, a monitoring on a longer period is required to guarantee the long-term stability and robustness of the treatment system.

\section{AUTHOR CONTRIBUTIONS}

$\mathrm{CC}$ and $\mathrm{MH}$ supervised the research project and the experiments. EL performed the metabarcoding analyses and interpretations. $\mathrm{AD}$ performed the CARD-FISH. CJ, FB-B, OB, and VT 
contributed to data interpretation. CC, EL, LF-R, MH, OB, and VT collected the samples. MH, EL, and CC wrote the paper. All authors read and approved the final manuscript.

\section{ACKNOWLEDGMENTS}

We thank the IngECOST-DMA project (ANR-13-ECOT-0009), the OSU OREME (SO POLLUMINE Observatory, funded since 2009), the BRGM and ADEME (Ph.D. fellowship of EL, 2016-2019) and the ADEME COMPAs project (GESIPOL

\section{REFERENCES}

Ahoranta, S. H., Kokko, M. E., Papirio, S., Özkaya, B., and Puhakka, J. A. (2016). Arsenic removal from acidic solutions with biogenic ferric precipitates. J. Hazard. Mater. 306, 124-132. doi: 10.1016/j.jhazmat.2015. 12.012

Amann, R. I., Binder, B. J., Olson, R. J., Chisholm, S. W., Devereux, R., and Stahl, D. A. (1990). Combination of 16S rRNA-targeted oligonucleotide probes with flow cytometry for analyzing mixed microbial populations. Appl. Environ. Microbiol. 56, 1919-1925.

Asta, M. P., Ayora, C., Acero, P., and Cama, J. (2010). Field rates for natural attenuation of arsenic in Tinto Santa Rosa acid mine drainage (SW Spain). J. Hazard. Mater. 177, 1102-1111. doi: 10.1016/j.jhazmat.2010.01.034

Baker, B. J., and Banfield, J. F. (2003). Microbial communities in acid mine drainage. FEMS Microbiol. Ecol. 44, 139-152. doi: 10.1016/S0168-6496(03) 00028-X

Baker, B. J., Hugenholtz, P., Dawson, S. C., and Banfield, J. F. (2003). Extremely acidophilic protists from acid mine drainage host rickettsialeslineage endosymbionts that have intervening sequences in their 16S rRNA genes. Appl. Environ. Microbiol. 69, 5512-5518. doi: 10.1128/AEM.69.9.55125518.2003

Barret, M., Briand, M., Bonneau, S., Préveaux, A., Valière, S., Bouchez, O., et al. (2015). Emergence shapes the structure of the seed microbiota. Appl. Environ. Microbiol. 81, 1257-1266. doi: 10.1128/AEM.03722-14

Battaglia, F., Morin, D., Garcia, J.-L., and Ollivier, P. (1994). Isolation and study of two strains of Leptospirillum-like bacteria from a natural mixed population cultured on a cobaltiferous pyrite substrate. Antonie Van Leeuwenhoek 66, 295-302. doi: 10.1007/BF00882763

Battaglia-Brunet, F., Dictor, M.-C., Garrido, F., Crouzet, C., Morin, D., Dekeyser, K., et al. (2002). An arsenic(III)-oxidizing bacterial population: selection, characterization, and performance in reactors. J. Appl. Microbiol. 93, 656-667. doi: 10.1046/j.1365-2672.2002.01726.x

Bertin, P. N., Heinrich-Salmeron, A., Pelletier, E., Goulhen-Chollet, F., ArsènePloetze, F., Gallien, S., et al. (2011). Metabolic diversity among main microorganisms inside an arsenic-rich ecosystem revealed by meta- and proteogenomics. ISME J. 5, 1735-1747. doi: 10.1038/ismej.2011.51

Brantner, J. S., Haake, Z. J., Burwick, J. E., Menge, C. M., Hotchkiss, S. T., and Senko, J. M. (2014). Depth-dependent geochemical and microbiological gradients in $\mathrm{Fe}$ (III) deposits resulting from coal mine-derived acid mine drainage. Front. Microbiol. 5:215. doi: 10.3389/fmicb.2014.00215

Brown, J. F., Jones, D. S., Mills, D. B., Macalady, J. L., and Burgos, W. D. (2011). Application of a depositional facies model to an acid mine drainage site. Appl. Environ. Microbiol. 77, 545-554. doi: 10.1128/AEM.01550-10

Bruneel, O., Duran, R., Casiot, C., Elbaz-Poulichet, F., and Personné, J.-C. (2006). Diversity of microorganisms in Fe-As-Rich acid mine drainage waters of carnoulès, France. Appl. Environ. Microbiol. 72, 551-556. doi: 10.1128/AEM. 72.1.551-556.2006

Bruneel, O., Héry, M., Laroche, E., Dahmani, I., Fernandez-Rojo, L., Casiot, C. (2017). "Microbial transformations of arsenic: from metabolism to bioremediation," in Metal-microbe Interactions and Bioremediation: Principle and Applications for Toxic Metals, eds S. Das and H. R. Dash (CRC Press: Abingdon).
2017/34/003) for the financial support. We thank Jennifer Hellal for helpful discussion about statistical analyses and the Montpellier RIO Imaging microscopy platform for their kind assistance in microscopy.

\section{SUPPLEMENTARY MATERIAL}

The Supplementary Material for this article can be found online at: https://www.frontiersin.org/articles/10.3389/fmicb. 2018.03169/full\#supplementary-material

Bruneel, O., Personné, J.-C., Casiot, C., Leblanc, M., Elbaz-Poulichet, F., Mahler, B. J., et al. (2003). Mediation of arsenic oxidation by Thiomonas sp. in acid-mine drainage (Carnoulès, France). J. Appl. Microbiol. 95, 492-499. doi: 10.1046/j. 1365-2672.2003.02004.x

Bruneel, O., Volant, A., Gallien, S., Chaumande, B., Casiot, C., Carapito, C., et al. (2011). Characterization of the active bacterial community involved in natural attenuation processes in arsenic-rich creek sediments. Microb. Ecol. 61, 793-810. doi: 10.1007/s00248-011-9808-9

Bryan, C. G., Marchal, M., Battaglia-Brunet, F., Kugler, V., Lemaitre-Guillier, C., Lièvremont, D., et al. (2009). Carbon and arsenic metabolism in Thiomonas strains: differences revealed diverse adaptation processes. BMC Microbiol. 9:127. doi: 10.1186/1471-2180-9-127

Candy, R. M., Blight, K. R., and Ralph, D. E. (2009). Specific iron oxidation and cell growth rates of bacteria in batch culture. Hydrometallurgy 98, 148-155. doi: 10.1016/j.hydromet.2009.04.013

Casiot, C., Morin, G., Juillot, F., Bruneel, O., Personné, J.-C., Leblanc, M., et al. (2003). Bacterial immobilization and oxidation of arsenic in acid mine drainage (Carnoulès creek, France). Water Res. 37, 2929-2936. doi: 10.1016/S00431354(03)00080-0

Chen, C.-J., and Jiang, W.-T. (2012). Influence of waterfall aeration and seasonal temperature variation on the iron and arsenic attenuation rates in an acid mine drainage system. Appl. Geochem. 27, 1966-1978. doi: 10.1016/j.apgeochem. 2012.06.003

Chen, L., Huang, L., Méndez-García, C., Kuang, J., Hua, Z., Liu, J., et al. (2016). Microbial communities, processes and functions in acid mine drainage ecosystems. Curr. Opin. Biotechnol. 38, 150-158. doi: 10.1016/j.copbio.2016.01. 013

Coupland, K., Battaglia-Brunet, F., Hallberg, K. B., Dictor, M.-C., Garrido, F., and Johnson, D. B. (2004). "Oxidation of iron, sulfur and arsenic in mine waters and mine wastes: an important role for novel Thiomonas spp," in Biohydrometallurgy; A Sustainable Technology in Evolution, eds M. Tsezos, A. Hatzikioseyian and E. Remoudaki (Zografou: National Technical University of Athens), 639-646.

Daims, H., Brühl, A., Amann, R., Schleifer, K. H., and Wagner, M. (1999). The domain-specific probe EUB338 is insufficient for the detection of all Bacteria: development and evaluation of a more comprehensive probe set. Syst. Appl. Microbiol. 22, 434-444. doi: 10.1016/S0723-2020(99)80053-8

Dave, S. R., Gupta, K. H., and Tipre, D. R. (2008). Characterization of arsenic resistant and arsenopyrite oxidizing Acidithiobacillus ferrooxidans from Hutti gold leachate and effluents. Bioresour. Technol. 99, 7514-7520. doi: 10.1016/j. biortech.2008.02.019

Dopson, M., Halinen, A.-K., Rahunen, N., Ozkaya, B., Sahinkaya, E., Kaksonen, A. H., et al. (2007). Mineral and iron oxidation at low temperatures by pure and mixed cultures of acidophilic microorganisms. Biotechnol. Bioeng. 97, 1205-1215. doi: 10.1002/bit.21312

Duquesne, K., Lebrun, S., Casiot, C., Bruneel, O., Personné, J.-C., Leblanc, M., et al. (2003). Immobilization of arsenite and ferric Iron by Acidithiobacillus ferrooxidans and its relevance to acid mine drainage. Appl. Environ. Microbiol. 69, 6165-6173. doi: 10.1128/AEM.69.10.6165-6173.2003

Edgar, R. C., Haas, B. J., Clemente, J. C., Quince, C., and Knight, R. (2011). UCHIME improves sensitivity and speed of chimera detection. Bioinformatics 27, 2194-2200. doi: 10.1093/bioinformatics/btr381 
Egal, M., Casiot, C., Morin, G., Elbaz-Poulichet, F., Cordier, M.-A., and Bruneel, O. (2010). An updated insight into the natural attenuation of As concentrations in Reigous Creek (southern France). Appl. Geochem. 25, 1949-1957. doi: 10.1016/ j.apgeochem.2010.10.012

Egal, M., Casiot, C., Morin, G., Parmentier, M., Bruneel, O., Lebrun, S., et al. (2009). Kinetic control on the formation of tooeleite, schwertmannite and jarosite by Acidithiobacillus ferrooxidans strains in an As(III)-rich acid mine water. Chem. Geol. 265, 432-441. doi: 10.1016/j.chemgeo.2009.05.008

Elbaz-Poulichet, F., Bruneel, O., and Casiot, C. (2006). "The Carnoules mine. Generation of As-rich acid mine drainage, natural attenuation processes and solutions for passive in-situ remediation," in Proceedings of the Difpolmine (Diffuse Pollution From Mining Activities), Montpellier, France.

Fabisch, M., Freyer, G., Johnson, C. A., Büchel, G., Akob, D. M., Neu, T. R., et al. (2016). Dominance of "Gallionella capsiferriformans" and heavy metal association with Gallionella-like stalks in metal-rich pH 6 mine water discharge. Geobiology 14, 68-90. doi: 10.1111/gbi.12162

Fernandez-Rojo, L., Casiot, C., Laroche, E., Tardy, V., Bruneel, O., Delpoux, S., et al. (in press). A field-pilot for passive bioremediation of As-rich acid mine drainage. J. Environ. Manage. 232, 910-918. doi: 10.1016/j.jenvman.2018.11.116

Fernandez-Rojo, L., Casiot, C., Tardy, V., Laroche, E., Le Pape, P., Morin, G., et al. (2018). Hydraulic retention time affects bacterial community structure in an As-rich acid mine drainage (AMD) biotreatment process. Appl. Microbiol. Biotechnol. 102, 9803-9813. doi: 10.1007/s00253-018-9290-0

Fernandez-Rojo, L., Héry, M., Le Pape, P., Braungardt, C., Desoeuvre, A., Torres, E., et al. (2017). Biological attenuation of arsenic and iron in a continuous flow bioreactor treating acid mine drainage (AMD). Water Res. 123, 594-606. doi: 10.1016/j.watres.2017.06.059

Fisher, J. C., Wallschläger, D., Planer-Friedrich, B., and Hollibaugh, J. T. (2008). A new role for sulfur in arsenic cycling. Environ. Sci. Technol. 42, 81-85. doi: 10.1021/es0713936

González-Contreras, P., Weijma, J., and Buisman, C. J. N. (2012). Continuous bioscorodite crystallization in CSTRs for arsenic removal and disposal. Water Res. 46, 5883-5892. doi: 10.1016/j.watres.2012.07.055

González-Toril, E., Aguilera, Á., Souza-Egipsy, V., Pamo, E. L., España, J. S., and Amils, R. (2011). Geomicrobiology of la zarza-perrunal acid mine effluent (Iberian Pyritic Belt, Spain). Appl. Environ. Microbiol. 77, 2685-2694. doi: 10. 1128/AEM.02459-10

Grettenberger, C. L., Pearce, A. R., Bibby, K. J., Jones, D. S., Burgos, W. D., and Macalady, J. L. (2017). Efficient low-pH Iron removal by a microbial Iron oxide mound ecosystem at scalp level run. Appl. Environ. Microbiol. 83:e00015-17. doi: 10.1128/AEM.00015-17

Hallberg, K. B., Coupland, K., Kimura, S., and Johnson, D. B. (2006). Macroscopic streamer growths in acidic, metal-rich mine waters in north wales consist of novel and remarkably simple bacterial communities. Appl. Environ. Microbiol. 72, 2022-2030. doi: 10.1128/AEM.72.3.2022-2030.2006

Hanert, H. H. (2006). “The genus Gallionella," in The Prokaryotes, eds E. Rosenberg, E. F. DeLong, E. Stackebrandt, S. Lory, and F. Thompson (New York, NY: Springer), 990-995. doi: 10.1007/0-387-30747-8_46

Hedrich, S., and Johnson, D. B. (2012). A modular continuous flow reactor system for the selective bio-oxidation of iron and precipitation of schwertmannite from mine-impacted waters. Bioresour. Technol. 106, 44-49. doi: 10.1016/j.biortech. 2011.11.130

Hedrich, S., and Johnson, D. B. (2014). Remediation and selective recovery of metals from acidic mine waters using novel modular bioreactors. Environ. Sci. Technol. 48, 12206-12212. doi: 10.1021/es5030367

Hedrich, S., Lünsdorf, H., Kleeberg, R., Heide, G., Seifert, J., and Schlömann, M. (2011). Schwertmannite formation adjacent to bacterial cells in a mine water treatment plant and in pure cultures of Ferrovum myxofaciens. Environ. Sci. Technol. 45, 7685-7692. doi: 10.1021/es201564g

Heinzel, E., Hedrich, S., Janneck, E., Glombitza, F., Seifert, J., and Schlömann, M. (2009a). Bacterial diversity in a mine water treatment plant. Appl. Environ. Microbiol. 75, 858-861. doi: 10.1128/AEM.01045

Heinzel, E., Janneck, E., Glombitza, F., Schlömann, M., and Seifert, J. (2009b). Population dynamics of Iron-oxidizing communities in pilot plants for the treatment of acid mine waters. Environ. Sci. Technol. 43, 6138-6144. doi: 10. 1021/es900067d

Hengen, T. J., Squillace, M. K., O’Sullivan, A. D., and Stone, J. J. (2014). Life cycle assessment analysis of active and passive acid mine drainage treatment technologies. Resour. Conserv. Recycl. 86, 160-167. doi: 10.1016/j.resconrec. 2014.01.003

Hovasse, A., Bruneel, O., Casiot, C., Desoeuvre, A., Farasin, J., Hery, M., et al. (2016). Spatio-temporal detection of the thiomonas population and the thiomonas arsenite oxidase involved in natural arsenite attenuation processes in the carnoulès acid mine drainage. Front. Cell. Dev. Biol. 4:3. doi: 10.3389/ fcell.2016.00003

Hug, S. J., and Leupin, O. (2003). Iron-catalyzed oxidation of Arsenic(III) by oxygen and by hydrogen peroxide: $\mathrm{pH}$-dependent formation of oxidants in the fenton reaction. Environ. Sci. Technol. 37, 2734-2742. doi: 10.1021/es026208x

Jackson, C. R., Churchill, P. F., and Roden, E. E. (2001). Successional changes in bacterial assemblage structure during epilithic biofilm development. Ecology 82, 555-566. doi: 10.1890/0012-96582001082[0555:SCIBAS]2.0.CO;2

Johnson, D. B., Hallberg, K. B., and Hedrich, S. (2014). Uncovering a microbial enigma: isolation and characterization of the streamer-generating, ironoxidizing, acidophilic bacterium "Ferrovum myxofaciens". Appl. Environ. Microbiol. 80, 672-680. doi: 10.1128/AEM.03230-13

Johnson, D. B., Kanao, T., and Hedrich, S. (2012). Redox transformations of Iron at extremely low pH: fundamental and applied aspects. Front. Microbiol. 3:96. doi: $10.3389 /$ fmicb.2012.00096

Jones, D. S., Kohl, C., Grettenberger, C., Larson, L. N., Burgos, W. D., and Macalady, J. L. (2015). Geochemical niches of Iron-oxidizing acidophiles in acidic coal mine drainage. Appl. Environ. Microbiol. 81, 1242-1250. doi: 10. 1128/AEM.02919-14

Jones, D. S., Lapakko, K. A., Wenz, Z. J., Olson, M. C., Roepke, E. W., Sadowsky, M. J., et al. (2017). Novel microbial assemblages dominate weathered sulfidebearing rock from copper-nickel deposits in the duluth complex, Minnesota, USA. Appl. Environ. Microbiol. 83:e00909-17. doi: 10.1128/AEM.00909-17

Jwair, R., Tischler, J. S., Janneck, E., and Schlömann, M. (2016). “Acid mine water treatment using novel acidophilic iron-oxidizing bacteria of the genus "Ferrovum": effect of oxygen and carbon dioxide on survival," in Proceedings of the IMWA 2016, eds C. Drebenstedt and M. Paul (Freiberg: IMWA), 1060-1063.

Kuang, J.-L., Huang, L.-N., Chen, L.-X., Hua, Z.-S., Li, S.-J., Hu, M., et al. (2013). Contemporary environmental variation determines microbial diversity patterns in acid mine drainage. ISME J. 7, 1038-1050. doi: 10.1038/ismej.2012.139

Kupka, D., Rzhepishevska, O. I., Dopson, M., Lindström, E. B., Karnachuk, O. V., and Tuovinen, O. H. (2007). Bacterial oxidation of ferrous iron at low temperatures. Biotechnol. Bioeng. 97, 1470-1478. doi: 10.1002/bit.21371

Legendre, P., and Gallagher, E. D. (2001). Ecologically meaningful transformations for ordination of species data. Oecologia 129, 271-280. doi: 10.1007/ s004420100716

Lyautey, E., Jackson, C. R., Cayrou, J., Rols, J.-L., and Garabétian, F. (2005). Bacterial community succession in natural river biofilm assemblages. Microb. Ecol. 50, 589-601. doi: 10.1007/s00248-005-5032-9

Macías, F., Caraballo, M. A., Nieto, J. M., Rötting, T. S., and Ayora, C. (2012). Natural pretreatment and passive remediation of highly polluted acid mine drainage. J. Environ. Manage. 104, 93-100. doi: 10.1016/j.jenvman.2012. 03.027

Magoè, T., and Salzberg, S. L. (2011). FLASH: fast length adjustment of short reads to improve genome assemblies. Bioinformatics 27, 2957-2963. doi: 10.1093/ bioinformatics/btr507

Méndez-García, C., Peláez, A. I., Mesa, V., Sánchez, J., Golyshina, O. V., and Ferrer, M. (2015). Microbial diversity and metabolic networks in acid mine drainage habitats. Front. Microbiol. 6:475. doi: 10.3389/fmicb.2015.00475

Meruane, G., Salhe, C., Wiertz, J., and Vargas, T. (2002). Novel electrochemicalenzymatic model which quantifies the effect of the solution Eh on the kinetics of ferrous iron oxidation with Acidithiobacillus ferrooxidans. Biotechnol. Bioeng. 80, 280-288. doi: 10.1002/bit.10371

Mueller, R. S., Dill, B. D., Pan, C., Belnap, C. P., Thomas, B. C., VerBerkmoes, N. C., et al. (2011). Proteome changes in the initial bacterial colonist during ecological succession in an acid mine drainage biofilm community. Environ. Microbiol. 13, 2279-2292. doi: 10.1111/j.1462-2920.2011.0 2486.x

Norris, P. R. (1990). "Acidophilic bacteria and their activity in mineral sulfide oxidation," in Microbial Mineral Recovery, eds H. L. Ehrlich and C. Brierley (New York, NY: McGraw Hill), 3-27.

Paikaray, S. (2015). Arsenic geochemistry of acid mine drainage. Mine Water Environ. 34, 181-196. doi: 10.1007/s10230-014-0286-4 
Rawlings, D. E., Tributsch, H., and Hansford, G. S. (1999). Reasons why 'Leptospirillum'-like species rather than Thiobacillus ferrooxidans are the dominant iron-oxidizing bacteria in many commercial processes for the biooxidation of pyrite and related ores. Microbiology (Reading, Engl.) 145(Pt 1), 5-13. doi: 10.1099/13500872-145-1-5

Rowe, O. F., and Johnson, D. B. (2008). Comparison of ferric iron generation by different species of acidophilic bacteria immobilized in packed-bed reactors. Syst. Appl. Microbiol. 31, 68-77. doi: 10.1016/j.syapm.2007.09.001

Santegoeds, C. M., Ferdelman, T. G., Muyzer, G., and Beerde, D. (1998). Structural and functional dynamics of sulfate-reducing populations in bacterial biofilms. Appl. Environ. Microbiol. 64, 3731-3739.

Schloss, P. D., Westcott, S. L., Ryabin, T., Hall, J. R., Hartmann, M., Hollister, E. B., et al. (2009). Introducing mothur: open-source, platform-independent, community-supported software for describing and comparing microbial communities. Appl. Environ. Microbiol. 75, 7537-7541. doi: 10.1128/AEM. 01541-09

Sheng, Y., Bibby, K., Grettenberger, C., Kaley, B., Macalady, J. L., Wang, G., et al. (2016). Geochemical and temporal influences on the enrichment of acidophilic iron-oxidizing bacterial communities. Appl. Environ. Microbiol. 82, 3611-3621. doi: 10.1128/AEM.00917-16

Sun, W., Xiao, E., Kalin, M., Krumins, V., Dong, Y., Ning, Z., et al. (2016). Remediation of antimony-rich mine waters: assessment of antimony removal and shifts in the microbial community of an onsite field-scale bioreactor. Environ. Pollut. 215, 213-222. doi: 10.1016/j.envpol.2016.05.008

Tardy, V., Casiot, C., Fernandez-Rojo, L., Resongles, E., Desoeuvre, A., Joulian, C., et al. (2018). Temperature and nutrients as drivers of microbially mediated arsenic oxidation and removal from acid mine drainage. Appl. Microbiol. Biotechnol. 102, 2413-2424. doi: 10.1007/s00253-017-8716-4

Tischler, J. S., Wiacek, C., Janneck, E., and Schlömann, M. (2014). Bench-scale study of the effect of phosphate on an aerobic iron oxidation plant for mine water treatment. Water Res. 48, 345-353. doi: 10.1016/j

Volant, A., Bruneel, O., Desoeuvre, A., Héry, M., Casiot, C., Bru, N., et al. (2014). Diversity and spatiotemporal dynamics of bacterial communities: physicochemical and other drivers along an acid mine drainage. FEMS Microbiol. Ecol. 90, 247-263. doi: 10.1111/1574-6941.12394

Wakao, N., Mishina, M., Sakurai, Y., and Shiota, H. (1984). Bacterial pyrite oxidation III. Adsorption of Thiobacillus ferrooxidans cells on solid surfaces and its effect on iron release from pyrite. J. Gen. Appl. Microbiol. 30, 63-77. doi: 10.2323 /jgam.30.63

Wallner, G., Amann, R., and Beisker, W. (1993). Optimizing fluorescent in situ hybridization with rRNA-targeted oligonucleotide probes for flow cytometric identification of microorganisms. Cytometry 14, 136-143. doi: 10.1002/cyto. 990140205
Wang, Q., Garrity, G. M., Tiedje, J. M., and Cole, J. R. (2007). Naïve bayesian classifier for rapid assignment of rRNA sequences into the new bacterial taxonomy. Appl. Environ. Microbiol. 73, 5261-5267.doi: 10.1128/AEM.00 062-07

Wang, Y., and Qian, P.-Y. (2009). Conservative fragments in bacterial 16S rRNA genes and primer design for $16 \mathrm{~S}$ ribosomal DNA amplicons in metagenomic studies. PLoS One 4:e7401. doi: 10.1371/journal.pone.0007401

Watanabe, T., Kojima, H., and Fukui, M. (2015). Sulfuriferula multivorans gen. nov., sp. nov., isolated from a freshwater lake, reclassification of "Thiobacillus plumbophilus" as Sulfuriferula plumbophilus sp. nov., and description of Sulfuricellaceae fam. nov. and Sulfuricellales ord. nov. Int. J. Syst. Evol. Microbiol. 65, 1504-1508. doi: 10.1099/ijs.0.000129

Weiss, J. V., Rentz, J. A., Plaia, T., Neubauer, S. C., Merrill-Floyd, M., Lilburn, T., et al. (2007). Characterization of neutrophilic Fe(II)-oxidizing bacteria isolated from the rhizosphere of wetland plants and description of Ferritrophicum radicicola gen. nov. sp. nov., and Sideroxydans paludicola sp. nov. Geomicrobiol. J. 24, 559-570. doi: 10.1080/014904507016 70152

Whitehead, P. G., Hall, G., Neal, C., and Prior, H. (2005). Chemical behaviour of the Wheal Jane bioremediation system. Sci. Total Environ. 338, 41-51. doi: 10.1016/j.scitotenv.2004.09.004

Wilmes, P., Remis, J. P., Hwang, M., Auer, M., Thelen, M. P., and Banfield, J. F. (2009). Natural acidophilic biofilm communities reflect distinct organismal and functional organization. ISME J. 3, 266-270. doi: 10.1038/ismej.2008.90

Woodcock, S., and Sloan, W. T. (2017). Biofilm community succession: a neutral perspective. Microbiology (Reading, England) doi: 10.1099/mic.0.000472 [Epub ahead of print].

Ziegler, S., Dolch, K., Geiger, K., Krause, S., Asskamp, M., Eusterhues, K., et al. (2013). Oxygen-dependent niche formation of a pyrite-dependent acidophilic consortium built by archaea and bacteria. ISME J. 7, 1725-1737. doi: 10.1038/ ismej.2013.64

Conflict of Interest Statement: The authors declare that the research was conducted in the absence of any commercial or financial relationships that could be construed as a potential conflict of interest.

Copyright (c) 2018 Laroche, Casiot, Fernandez-Rojo, Desoeuvre, Tardy, Bruneel, Battaglia-Brunet, Joulian and Héry. This is an open-access article distributed under the terms of the Creative Commons Attribution License (CC BY). The use, distribution or reproduction in other forums is permitted, provided the original author(s) and the copyright owner(s) are credited and that the original publication in this journal is cited, in accordance with accepted academic practice. No use, distribution or reproduction is permitted which does not comply with these terms. 